\section{Accounting: what balance is there between universality and \\ contingency?}

Alain BURLAUD,

Conservatoir national des arts et métiers,

E-mail: Alain.Burlaud@cnam.fr

Geneviève CAUSSE,

Université Paris-Est

Creteil et ESCP Europe,

\section{Alstract}

The question regarding the universal or contingent character of accounting is essential because it determines one of the dimensions of the governance of organizations. The first part of the article shows the dynamics of universality, that is, the movement towards a single set of global standards. The second part shows the limits of this movement and, conversely, the relevance of standards adjusted to local contingencies and coercions. Finally, the third part deals with the balance between these two concepts of accounting.

Keywords: accounting; universality; contingency JEL Classification: M40

To cite this article:

Burlaud, A. and Causse, G. (2018), Accounting: what balance is there between universality and contingency?, Audit Financiar, vol. XVI, no. 1(149)/2018, pp. 89-100,

DOI: 10.20869/AUDITF/2018/149/001

To link to this article:

http://dx.doi.org/10.20869/AUDITF/2018/149/001

Received: 27.06.2017

Revised: 12.09 .2017

Accepted: 13.09.2017 


\section{Introduction}

Accounting is a technique that dates back to the beginning of time (Degos, 1998). Jean Fourastie was the first to develop a historical theory of accounting. As an economist, but also as a professor, he considered that teaching accounting without historical reference is as illogical and as dangerous as "teaching music where there would be no place for the works of Bach" (Fourastié, 1976, p. 59) ${ }^{1}$.

Accounting is inherent to social life. It "was born from the organized activity needed by life in society: the homo computator was part of the homo faber" (Cossu, 2008) ${ }^{2}$ (the homo computator being, according to the author, an avatar of homo œconomicus and homo socius).

If at the beginning the main objective of accounting was to memorize quantitative data related to agro-pastoral activities and transactions between traders, the economic development, the necessity of a tool for "reporting" quickly appeared. The division of functions, between those of the agent (the shepherd, the farmer, the trader etc.) and those of the decision-maker, brought about this necessity.

The system was then technically improved. The important step is the publishing of the work of Pacioli, the Summa de arithmetica, geometria, proportioni et proportionalita, in 1494.

Then, in the $19^{\text {th }}$ century, accounting made significant progress for the arrival of capitalism. Managers had to be accountable to the capital owners and they wanted to have the necessary information for decision-making and sharing the profit. The State was equally involved in this sharing, which quickly led to the need to set accounting standards. Each country had its own accounting regulations which had been drawn up according to the purpose assigned to accounting, according to the needs of the different users of the information and the material and human resources available in the country.

It was therefore possible to consider that accounting was inherent to capitalism. But, curiously, it was also claimed to be essential for the development of communism. "Accounting, the ideal control and synthesis of the process, becomes the more necessary the more the

\footnotetext{
1 The first edition dates back in 1943.

2 Extract from the foreword of the work "Les origins de la comptabilité" which was not finished in time by $\mathrm{C}$. Cossu
}

production takes place on a social scale and loses its purely individual character; therefore, the more necessary it is in the capitalist production, disseminated by craftsmen and peasants, the more necessary it is in the community production than in the capitalist production" (Marx, 1968, p. 573).

We can see that each economic current, and even every ideology, tries to assume the monopoly of accounting and to shape it accordingly to the sought objective and the context. "Accounting is not only a tool ... it is a social phenomenon" (Capron, 1993, p. 9).

But in the age of globalization, capitalism has imposed itself in almost all countries of the world. Therefore, the question of the purpose to be assigned to accounting within this global context has arisen. We are faced with the following alternative: have the accounting needs become universal or should we rather continue to consider that the needs of the users may differ in respect of entities (familyrun companies, listed companies, NGOs, public organizations, etc.), countries, cultures or economic areas? We are faced with the following dilemma: universality or contingency?

After examining the fundamentals and contributions of each of these options, we will attempt to answer the question of whether a balance is possible between the two extremes.

\section{Universality}

Universality is based on the constraints of globalization and financialization, on the fact that the needs of users are identical in all countries, on the necessity to be able to compare financial statements, on the principle of neutrality and transparency of information and the search for the general interest.

\subsection{The constraints of globalization and financialization}

The globalization of the economy in the latter part of the 20th century was a major change in an extremely short period of time. Thus, the world exports increased from 2,000 billion dollars in 1960 to 16,000 in 2008

(CNUCED, 2009, p. 9). But this globalization is not limited to trade in goods and services; it is accompanied by cross-border investments which represent a new form 
of competition with relocations. Therefore, the global inflows of foreign direct investment have evolved as it follows (Wikipedia, 2017):

- 1985: 50 billion dollars;

- 1989: 200 billion dollars;

- 2007: 2,000 billion dollars;

- 2013: 1,400 billion dollars.

These investments correspond largely to the increase in number of multinational enterprises, from over 37,000 (with 170,000 subsidiaries and 20 million employed people) in 1990 to 70,000 companies $(69,000$ subsidiaries and 57 million employed people) in 2004 (Becuwe etal., 2007, p. 323). This development of companies is accompanied by the evolution of their manner of financing. Thus, the share issues in total external financing (equity + bonds + bank debts) changed as it follows (Plihon et al., 2013, p. 33):

$$
\begin{aligned}
& -\quad 1980: 2.8 \% ; \\
& -\quad 1990: 31.0 \% ; \\
& -\quad 2008: 42.3 \% \text {. }
\end{aligned}
$$

More than $50 \%$ of these securities are held by institutional investors (Plihon et al., 2013, p. 33) illustrating the financialization of the economy.

The most dynamic form of capitalism is that of financial capitalism, which is particularly characterized by stockexchange nomadism and the search for a rapid profit in the form of dividends or capital gains. It is the reign of shareholder value as opposed to the patrimonial value of the family-run firm whose shareholding is stable and is managed from a perspective of transmission between generations.

The need for financial information is obviously different according to the users, their objectives, their decisionmaking model. However, the institutional investors, whose portfolio does not know the borders of states, have common needs which can be summarized as comparability, neutrality and transparency of the financial information in order to be able to perform the arbitrations (purchase, maintain or sell the securities) at the best. In this respect, assuming that its unique purpose is to serve the interests of investors, accounting is universal, i.e. the demand is the same regardless of the place or nationality of these investors. This is the reason why the international accounting standards, IFRSs, have been developed. Moreover, it should be noted that they are more precisely standards of financial reporting, since they focus only on one end of the accounting chain, that is, the final product which consists in disclosing financial statements. First and foremost, the process of producing information (codification of accounts, entry of records, control, etc.) is not standardized.

\subsection{A user without borders}

The IFRS Conceptual framework clearly announces the served interests.

"The objective of general purpose financial reporting is to provide financial information about the reporting entity that is useful to existing and potential investors, lenders and other creditors in making decisions about providing resources to the entity. Those decisions involve buying, selling or holding equity and debt instruments, and providing or settling loans and other forms of credit" (The Conceptual Framework for Financial Reporting, ES/2015/3, 1.2). "Decisions by existing and potential investors about buying, selling or holding equity and debt instruments depend on the returns that they expect from an investment in those instruments, for example dividends, principal and interest payments or market price increases" (The Conceptual Framework for Financial Reporting, ES/2015/3, 1.3). "Other parties, such as regulators and members of the public other than investors, lenders and other creditors, may also find general purpose financial reports useful. However, those reports are not primarily directed to these other groups" (The Conceptual Framework for Financial Reporting, $\mathrm{ES} / 2015 / 3,1.10$ ).

The decisions to be made, mainly equity arbitrations, suppose that general information, which can be completed at the request of investors, is comparable, neutral and transparent, so that markets could be efficient.

\subsection{Comparability}

The IFRS Conceptual Framework defines comparability as: 'Users' decisions involve choosing between alternatives, for example, selling or holding an investment, or investing in one reporting entity or another. Consequently, information about a reporting entity is more useful if it can be compared with similar information about other entities and with similar information about the same entity for another period or 
another date" (The Conceptual Framework for Financial Reporting, ES/2015/3, 2.23). Therefore, comparability involves two dimensions: space (comparing different entities) and time (for the same entity, comparing financial statements with different dates).

If the spatial dimension is a priori relevant for an international and nomadic shareholder, it supposes, however, that there are comparable entities. Yet, the large multinational companies with tens or even hundreds of subsidiaries, are not strategically and operationally comparable. They do not have the same portfolio of activities as a result of corporate growth and do not have the same business model (type of customers, image, $R$ \& $D$, relationships with subcontractors, etc.). Only the financial performance is comparable as the company is considered only as an investment and not an institution and the standards for measuring this performance are the same for all.

Comparability over time is obviously useful, but it does not require identical accounting standards for entities which do not belong to the same group. It merely supposes the consistency of methods, which can be done without the necessity of resorting to standards and, a fortiori, to global standards.

In conclusion, it can be noticed that the requirement of comparability in space and time justifies the existence of universal norms only in a limited number of cases: that of entities with very similar activities and business model. In addition, the comparison of financial statements makes sense only for entities competing on the capital market: the investors need to compare in order to arbitrate, the banks in order to finance. It should also be remembered that the comparison can also make sense for suppliers, customers and employees, concerned about the performance and sustainability of the entity.

\subsection{Neutrality}

The IFRS conceptual framework defines the neutrality as: "A neutral depiction is without bias in the selection or presentation of financial information. A neutral depiction is not slanted, weighted, emphasised, de-emphasised or otherwise manipulated to increase the probability that financial information will be received favourably or unfavourably by users. Neutral information does not mean information with no purpose or no influence on behaviour. On the contrary, relevant financial information is, by definition, capable of making a difference in users' decisions" (The Conceptual Framework for Financial Reporting, ES/2015/3, 2.17).

This definition of neutrality leads to two remarks. If neutrality implies a lack of prejudice in the selection or disclosure of financial information, then it should satisfy all users and, therefore, it should produce financial information of universal value. But in the same definition, the Conceptual Framework states that financial information should have the ability to influence the decisions of users. The nature of the decisions to be made being different from one category of users to another, we cannot see how this financial information could then have a universal value. This qualitative characteristic is thus defined in a contradictory manner.

\subsection{Transparency}

One of the major characteristics of accounting is to ensure the follow-up of financial flows and, therefore, to contribute to transparency ${ }^{1}$ without which there can be no trust, trust that is the bond of the Society as well as the bond of the business world.

Curiously, neither the Constitution of the IASB Foundation, nor the IFRS Conceptual Framework, nor the European Directive of 2013 on annual financial statements, nor the Plan Comptable Général (PCG - the French accounting standards) of 2014, uses, at any time, the word "transparency." This term is no longer mentioned in the Constitution of IFAC. This is the more surprising as transparency implies the need of a common language to make sure that the information is properly produced and interpreted by different users. It is also not mentioned by the codes of ethics of IFAC, the French Chamber of Auditors and the French Institute of Chartered Accountants.

Opposed to opacity, transparency is one of the conditions for the existence of the Rule of Law. This does not mean that everything must be known by everyone. There are, of course, "access rights", as computer scientists say, because otherwise there would be no more privacy or business secrecy, secrecy that may be necessary and does not necessarily cover corrupt behaviour.

Transparency can be "intermediated." Therefore, the auditor has access to all the documents of his client

1 On the subject of transparency, also see: Burlaud and Colasse (2010a) and Burlaud (2017). 
which are useful for the performance of his mission and it is through his intermediary that third parties know that they do not contain any components or elements that reveal criminal acts. It should be added that the access rights are not transmittable. Thus, certain recipients of information also have to respect an obligation of discretion (for example, the elected members of the works council) or professional secrecy (for example, the auditor or chartered accountant).

If the need for transparency is universal, the way in which it is answered depends on the degree of openness to the access rights (secrecy is not protected everywhere in the same way, for example, as in the case of banking secrecy) or the contingent balance between transparency which allows exercising a social control and the trade secret which allows to neutralize possible hostile actions.

\subsection{The pursuit of the public interest}

The pursuit of the public interest, which can be opposed to the defence of a particular interest, pleads for universality. This is the main argument for the legitimization of the legislator or the standard-setter who is, in a sense, a legislator by delegation. This concept has a very strong evocative power. The Constitution of the IFRS Foundation uses the term "public interest" eight times in 19 pages and that of IFAC 28 times in 17 pages.

None of the standard-setters defines the public interest; they merely provide an institutional response in terms of governance.

For the IFRS Foundation, the 22 trustees undertake to act for the public interest (Constitution, article 6). It is stipulated that:

- "The mix of Trustees shall broadly reflect the world's capital markets and diversity of geographical and professional backgrounds." (art. 6)

- "The Trustees shall comprise individuals that, as a group, provide an appropriate balance of professional backgrounds, including auditors, preparers, users, academics, and officials serving the public interest. Normally, two of the Trustees shall be senior partners of prominent international accounting firms. To achieve such a balance, Trustees should be selected after consultation with national and international organisations of auditors (including the International Federation of Accountants), preparers, users and academics." (art. 7)

This shows that, for the IASB, the public interest summarises more the interest of the financial markets and the trustees are essentially professionals appointed by professionals.

For IFAC, the Constitution provides a Public Interest Oversight Board without further details.

These institutional responses illustrate the difficulty of defining the public interest. To constitute an assembly of technically competent persons whose integrity is beyond doubt is not sufficient to guarantee a good representation of the public interest. ${ }^{1}$

The public interest is by nature a fuzzy and contingent notion. It has mainly a political character. In the absence of an accurate definition, is this concept included in the regulatory framework itself? The IFRS conceptual framework does not mention it once. The same applies to the 2013 Accounting Directive and the French standards. In neither of these documents has the public interest been able to find an operational translation and contribute to the universality of the standard.

In conclusion, we notice that a global financial market logically calls for universal accounting standards to compare the financial performance of entities, considered as simple investment opportunities. As a result, the financial statements must be neutral and contribute to the transparency of the transactions which ensure the trust without which the market cannot function.

Clearly, the IFRSs are produced by a professional and private-sector law institution claiming to be of public interest (IFRS Foundation, Constitution, art. 6). It is obviously paradoxical that a standard-setter whose main concern is to improve the functioning of the financial market can rely on it. This postulates that satisfying investors means satisfying all the stakeholders, which remains to be verified. We will see that contingency factors may invalidate this hypothesis.

\section{Contingency}

Contingency is based on taking into account the impact of standards (consequentialism), the economic and

1 On the subject also see: Burlaud and Colasse, 2011. 
social environment, the specific needs of users (the relevance of information), and the compliance with the applicable law rules. Moreover, it leaves room for professional judgment and consideration of the business model of the different entities.

\subsection{Consequentialism}

The set of accounting principles constitutes the basis of the "accounting system." According to the contingency theory, it is necessary to integrate the economic and social consequences resulting from the application of these principles, i.e. beyond the regulatory framework. Accounting is not just a technique; its application has consequences for stakeholders. Considering that the accounting system can contribute to the establishment of a more just society, one can talk about the ethics of accounting.

"It is no longer a question of favouring the pursuit of a (the?) truth that would always be good to say, but of looking for information that does not produce harmful effects" (Burlaud and Baker, 2015, p. 57). Consequently, there is room left to the judgment of the professional accountant.

Compliance with regulations is not enough, accounting has a regulatory function which can only be assured by the implementation of devices acting on conduct. Professional institutions specify the duties of their members in a code of ethics.

\subsection{Relevance of financial reporting}

The purpose of financial reporting is to provide the user with relevant data at the right time to make enlightened decisions. The problem is that the users are numerous and that, consequently, the decisions to be made are not similar. The users are more or less numerous according to whether there is adopted the partnership approach or the shareholder approach.

According to the partnership approach, the list of stakeholders is abundant. It is customary to distinguish among the stakeholders: internal users, managers, employees, external users, lenders, suppliers and other creditors, the tax administration, and even the society in general. Each of the stakeholders has different needs. Thus, if the employee wants to judge the sustainability of the company, the creditors are more interested in solvency. Naturally, each category is not given particular attention in the regulation. The information is as wide as possible, intended for the general public.

According to the shareholder approach, the agency relationship is limited to the relationship between shareholders and management. The publication of accounting and financial information is relevant as long as it provides a solution to the information asymmetry between the agent (manager) and the principal (the shareholder). It aims to promote optimal decisions in terms of resource allocation.

It should be noted that, in case of a listed company, the information is relevant to investors when helping to make predictions. Numerous studies show changes in stock prices according to the announcement of accounting and financial results.

The expectations of each actor depend, therefore, on the position taken in the company, generally, on the contract that relates it to the company. They also depend on other factors, such as legal status, economic and social context.

Therefore, in France, whose economic environment is mainly composed of small companies, the objective of comparability of information with a foreign company is not primordial. Moreover, for various reasons, these companies do not use external financing. Consequently, if the banker needs information when asked to fill a cash deficit, the banker can always ask it to the managers, as well as information about their personal patrimony. This is not the case of the national or international investment funds, which are not interested in this type of companies.

In terms of the need for information, the economic and social context is particularly important in the developing countries because "the accounting systems are actively involved in the economic and social development of countries. Not only do they allow the management of entities that use them, companies and other organizations [cooperatives, NGOs, etc.] but they are also instruments to help the national economic planning" (Causse, 2009, p. 702). Given the specific objectives of the developing countries and the means at their disposal, it may even be questioned the fact whether the international standards, developed in a very different context, represent rather a barrier to their development ${ }^{1}$.

${ }^{1}$ Also see Causse and Ebondo (2015, p. 39). 
They widely meet needs which do not exist in the countries under consideration.

To sum up, users do not form a homogeneous category and the needs are not universal.

\subsection{The connection to the law}

In France the accounting regulations, as developed during the $19^{\text {th }}$ century, resulted in a homogeneous corpus called the legal accounting system. "Therefore, in respect of the enterprise and more generally the private sector, the Lex mercatoria in the Middle Ages, the royal ordinances, such as those of Colbert in 1673 under the old regime, certify the apprehension of the accounting field by law, regardless of its form. After the Revolution, the codification of the accounting practices of enterprises in a commercial code in 1807, renewed in 1867 , certifies this willingness of the public power to govern the private accounting by a restricted and identifiable set of legal norms" (Kott, 2014, p. 40). As the author points out, the 1866 French companies act contains the regulations related to the accounting of merchants, the financial statements and the statutory auditors.

This system includes principles contained in the commercial code (definition of equity, consistency of methods, prudence principle, etc.), it sets out the duties of the accountant and defines the accounting practices (chronological recording, maintenance of documents, etc.). The principle of patrimony, according to which the annual accounts must give a true and fair view of the financial position and the profit or loss of the company, is included in the French code of commerce (article 9).

As it has been noted by many authors (Burlaud, Poitrinal and Salustro, 1998; Raybaub and Teller, 2009), there are strong links between accounting and law, and accounting has even been described as the "algebra of the law" (Garnier, 1947). The particularities of the accounting law in comparison to the commercial law give it a certain autonomy. Thus, in accounting, "the business entity" is considered as an accounting subject. Similarly, in accounting, goods are apprehended in accordance with their economic purpose, that is, according to the intention to own them or not in a sustainable manner. Securities, for example, can be considered either as fixed assets or current assets. Despite the fact that this economic dimension is taken into account, it cannot be described as economic law.
The Ministry of Finance is responsible for drafting legal standards, which apply to the private sector and the public sector. They constitute a homogeneous system ${ }^{1}$. The state is a stakeholder with more than one dimension. "Taxation has a double influence on accounting, a direct influence by the rules that concern the book entries, an indirect influence that influences the management decisions and thus their accounting record" (Rossignol, 1999, p. 6).

The State also intends to play the role of regulator: "The sacred union of law and accounting for the protection of capitalism takes thus the form of accounting offenses and it is only at the beginning of the $20^{\text {th }}$ century when the accounting standardization process started. The transition to a so-called planned economy is accompanied by a political objective of state control of accounts both for economic and fiscal reasons" (Muller, 2014, p. 36).

However, in the 70 s/80s, the process of international standardization appears to be disconnected from the law. The beginning of financial capitalism has disrupted the system on one hand to the point of splitting the statecontrolled accounting system which continues to apply to the non-consolidated financial statements (PCG in France), and on the one hand, the international standardization by a private institution, which applies to the consolidated financial statements. The principle of legal patrimony, which is dominant in the French accounting, runs up against the pre-eminence of the economic substance over legal form in the IFRSs. Accounting is no longer a reflection of the legal position of the company but of its economic situation. The international accounting standards have been liberated from the business law.

The assessment of the economic situation can only be achieved by using more or less sophisticated evaluation methods. The accountant economist has replaced the lawyer. "Previously the accounts were false, and everyone knew, the problem with the international standards is that the accounts are always false but everyone believes they are true" ${ }^{\prime 2}$.

The objective of the international standard setters, which is to prepare and enforce recognized universal rules, is

1 The culmination of which is the LOLF (Organic Law on Finance Laws) of 2001

2 This remark, attributed to W. Nahum, is reported by J. Haas (2014, p. 21). 
not however achieved. For many countries, logic remains the respect of contingency.

\subsection{Place given to professional judgement}

"The professional accountant is critical throughout his mission: he exercises his professional judgment ${ }^{1}$ mostly for deciding on the nature, calendar and scope of the procedures to be implemented on the basis of the information gathered" (Professional accounting norm, abrogated in June 20, 2011). The exercise of this judgment, which introduces a degree of freedom in relation to regulation, is justified by several reasons:

- First, because the standard setter could not foresee all situations;

- Then, in certain situations, it is necessary to use the knowledge that the expert can have on the company and its environment in order to assess the consistency and the verisimilitude of the accounts;

- Finally, the texts sometimes call for judgment, for example when the materiality principle is to be applied.

Naturally, in exercising a professional judgment, the fundamental principles intended to ensure the quality of information must be respected. As outlined in a document issued by the Canadian Institute of Chartered Accountants (CICA) from February 2013, entitled "Professional Practice Exercise", "The professional judgment does not allow an accountant to choose a method simply because nothing forbids it". When freedom is dropped in respect of choosing an accounting method, a justification of this choice must be provided.

The place given to professional judgment fills up a larger space in audit. In fact, the exercise of audit, mainly the identification of risks and the planning of interventions involve connecting the facts, the ability to detect anomalies and the ability to judge. "A high-quality audit depends on the ability of auditors to exercise appropriate and relevant professional judgment throughout their engagement" (IAASB, 2016, 6).

As a result of the financial scandals, particularly the bankruptcy of Lehman Brothers, which has accused the auditors more for a lack of risk detection than for a

\footnotetext{
1 On the concept of professional judgement see Burlaud and Niculescu (2016).
}

failure to respect the audit process, the professional judgment has been given more importance.

\subsection{Taking into account the business model}

The business model is a tool for describing and understanding how an organization creates value through the implementation of a set of activities, processes, networks, resources, and the use of key competences. It is based on a systemic vision of the company.

It is a recent concept, and therefore virtually absent from the regulation. However, based on the principle that accounting should be responsible for the transactions relating to the company's business during the past period and should provide information relevant to the decision of the relevant stakeholders, the concept of a business model is important.

Accounting can be considered "as an instrument for modelling the company" (Colasse, 2008, p. 185), which makes it a compulsory tool for building the trust between the economic and social actors.

Taking into account the business model may result in the provision of non-financial information, as well as information on intangible assets or accounting choices, which are often characteristic of the entities profile.

However, "In addition to IFRS 9, there is no explicit reference to the business model in the IFRSs, reflecting the IASB's prudence in respect to this concept. The reasons for this caution are related to the risk of focusing on the use of the accounting of intention (management Intent) rather than the principles of neutrality and comparability of financial statements" (Barneto, Degos and Ouvrard, 2015, p. 14). This probably explains why the few studies on the subject (Disle et al., 2016) indicate that, if the concept is present in the academic literature, it is little integrated into the national and international standards.

To sum up, the ethical dimension of accounting, the heterogeneousness of users and their needs, the necessity to leave room to the exercise of professional judgment and to take into account the business model, mean that accounting is logically contingent to the economic, legal and social context of the countries. 


\section{The balance between the universality and contingency}

Universality tries to stand out as a constraint due to the globalization and financialization of the economy. It does not lack advantages as the foundations on which it is based have shown. But, on the other hand, we have considered that accounting is logically contingent. Consequently, is the solution not a balance between the two extremes?

To try to answer the above question, we first perform an observation of the adoption of international standards at a global level nowadays and we analyse the requirements of the adoption of a global standard.

\subsection{The actuality of the adoption of the IFRS standards}

To believe the IFRS Foundation, ite missa est, the IFRS have conquered the world. One can thus read on the official site (http://www.ifrs.org/Features/Pages/Globalreach-of-IFRS-is-expanding.aspx.): "Nearly all (93\%) of the jurisdictions have publicly expressed support for a single set of high-quality global accounting standards. And the relevant authority in nearly all (94\%) of the jurisdictions has made a public statement supporting IFRS as the single set of global accounting standards. Even in those few countries that have not publicly supported IFRS, IFRS is commonly used by publicly accountable entities in half of the jurisdictions." But at a closer look, beyond the lack of modesty of the text, the picture is not so glorious. The percentages given above are correct if we consider, for example, that the Fiji Islands or Macedonia weight as much as the US or China! Among the countries that have not adopted the IFRSs, there are still these two enormous countries. Other large countries do not allow or require them than for at least some public interest entities (PIE): India, Japan and Switzerland. France is ranked within the 116 countries that require the application of IFRS for all or most of the PIEs. But the IASB fails to mention that in the latter case, this concerns only the consolidated financial statements. The layout would be totally different if we measured the adoption of IFRSs areas by weighting the responses of different countries, for example by GDP. Finally, these statistics are based on statements, not on observations. So, in some developing countries having formally adopted the
IFRSs, and we know that the accounting profession is virtually non-existent and that standards are not actually applied.

Taking into consideration the SMEs, the results are even less unanimous in favour of the IFRSs. Thus, Nobes (2011, p. 43) lists 65 countries that prohibit the use of IFRSs for SMEs, 57 countries that allow them and 6 countries that have made them compulsory. Moreover, when looking at the list of countries in detail, we see that within the group of countries prohibiting IFRSs for SMEs there are practically all big countries of the planet: Germany, Canada, China, Spain, the United States, France, India, Italy, Japan, the United Kingdom, Russia, etc. Only three big countries allow the use of IFRSs for SMEs: South Africa, Brazil and Turkey. The six countries making them compulsory are Chile, Fiji, Macedonia, Rwanda, Serbia and Venezuela.

These figures show that the reality lies between universality and contingency, i.e. local standards and relevance in respect to the needs expressed locally. It is clear that the financial statements published by PIEs operating on international markets must be standardized according to the international standards, but even this is not accepted everywhere depending on the balance of power. Thus, China and the United States keep their own standards. On the other hand, for the companies with national activity and which are not PIEs, the statements drawn up in compliance with the local standards are the rule.

\subsection{Is there a global standard feasible?}

The search for a balance between the local standards and the international ones is difficult because we find ourselves between two worlds whose essential characteristics are in opposition:

- A legal accounting as opposed to an economic accounting;

- An accounting for the general public against an accounting for the financial investors;

- An accounting whose standards are set by a public entity in opposition to an accounting whose rules are generated by a private entity.

The project to create a single global set of accounting standards has been the subject of reflections of the highest professional bodies in France. We refer to the writings and speeches of Jérôme Haas, Chairman of the 
French Accounting Standards Authority ${ }^{1}$, whose main ideas are set out below.

According to him, there is first a common problem of terminology. For being convinced of this, one should make reference to the true and fair view. In the French culture, this means "secure, certified figures, anchored in the law", in the English culture, they are "figures for investors prevalently, varying with the conjuncture, not anchored in the law, ....".

Then, according to Haas, the financing method leads to considering different horizons. When companies are financed mainly by equity, which is the case of France, they have a longer-term vision in comparison with the companies that rely mainly on the financial markets, which is the case of the United States.

Finally, the dominant business model, as well as the degree of sophistication of the economy are very different according to the countries or the geographical areas. Therefore, in the developing countries, most of the economic entities are very small, belonging mainly to the agriculture and craft sector. They cannot be subjected to complex standards which do not meet any of their needs.

On the basis of these findings and the manner in which the international standards were developed and applied, Haas sets the conditions for the introduction of a single international accounting standard.

The following basic conditions must be met:

- The choice "between fair value and historical cost, between relevance and transparency, between the representation of the past or the taking into account of hypotheses on the future", a clear separation must be made and appear between what is safe and what is calculated;

- "The assessment of standards by a public authority according to the procedures controlled by itself and its peers".

\footnotetext{
1 Thus: The speech delivered on April 6, 2011 at the meeting of the French Association of Corporate Treasurers (AFTE), entitled "The wonderful project of creating a single global accounting standard" and the interview published in the Small Posters No. 44, of March 3, 2011, p. 5, entitled "We must strike the right balance between local standards and international standards." What is repeated textually is in quotation marks.
}

It is also necessary to:

- Envisage the relevance of a system of options sustained by the existence of different contexts;

- Test the impact of the introduction of a standard;

- Maintain "a continuous dialogue with the assembly of stakeholders at a global level".

To those conditions, he added that it must:

- "End the convergence policy", as it is currently being carried out and leads to contrary results to the sought objectives, for example, the one of comparability,

- Admit that a "single set of standards developed for the financial markets cannot be the benchmark for the countries where the use of financial markets is virtually non-existent, nor for SMEs".

Consequently, without giving up to the possibility of creating a single global accounting standard, for the moment this project holds to "the adventure of Babel", it seems utopian.

\section{Conclusion}

In this paper, we wanted to look for the relevance of a universal accounting versus a contingent accounting in relation to the economic, legal and taxation characteristics of the companies.

It is clear that the accounting standards are essential. They are part of the rule of law because they allow taxation in respecting the equal treatment of taxpayers, natural or legal persons. They ensure the traceability of the financial flows to fight against corruption and tax evasion.

Should these standards be global? We have seen that nowadays, if they are formally adopted by a very large majority of countries, the biggest ones, including the United States and China, they should not. Other large countries express reservations or, like most European countries, limit their use to the consolidated financial statements of PIEs. This means two things:

- The multinational groups, large firms (the Big Fours) and analysts need globally recognized rules in order not to have to comply with several reporting standards; 
- The other companies and the users of their annual financial statements need standards adapted to local situations.

We observe that the area of local regulatory systems almost always corresponds to the borders of the States because the link between accounting, law and taxation remains very strong. In the absence of a European tax law, there are no very compelling European standards, as the accounting directive is not very detailed and leaves room for 27 or 28 national standards. On the other hand, the 17 countries of the Organization for the Harmonization of Business Law in Africa (OHADA) went further and adopted a common accounting framework: the OHADA Accounting System (SYSCOHADA) (Causse, Gouadain and Mifetou, 2011). It is based on a common business law. Moreover, the taxation rules of the member countries, if not identical, are of common inspiration since they stem from the general French taxation code. Finally, the level of development of these countries is relatively comparable.

But a regulatory system cannot foresee all the present and, a fortiori, future scenarios. It is therefore necessary to leave room for the exercise of the professional judgment of the preparers of the financial statements and their auditors ${ }^{1}$. The search for the relevance of financial information also implies the possibility of integrating the features of each entity, its business model, its environment, etc.

In the end, we observe that the setting of accounting standards is an eminently political act ${ }^{2}$, therefore, an art of compromise, a compromise between the principle of the universal rule, apparently simple but not necessarily relevant, and national or regional rules better adapted to specific contexts.

\section{REFERENCES}

1. Barneto, P., Degos, J-G. and Ouvrard, S. (2015), Normes financières et modèle économique : Comment concilier neutralité, comparabilité et pertinence de l'information publiée? La Revue des Sciences de Gestion, vol. 273-274, issue 3, pp. 1320, DOI 10.3917/rsg.273.0013.

2. Becuve, S. (coord.) (2007), Economie, Nathan.

3. Burlaud, A. and Baker, C.R. (2015), The Historical Evolution from Accounting Theory to Conceptual Framework in Financial Standards Setting, The CPA Journal, August, pp. 54-60.

Burlaud, A. and Colasse, B. (2010), Normalisation comptable internationale : le retour du politique?, Comptabilité, contrôle, audit, vol. 16, no. 3, pp. 153, DOI 10.3917/cca.163.0153.

5. Burlaud, A. and Colasse, B. (2010b), Standardizarea contabilă internațională:

reîntoarcerea politicului? (I), Audit Financiar, vol. 8, nr. 61.

6. Burlaud, A. and Colasse, B. (2010c), Standardizarea contabilă internațională: reîntoarcerea politicului? (II), Audit Financiar, vol. 8, nr. 62.

\footnotetext{
${ }^{1}$ See also Burlaud and Niculescu (2016)
}

7. Burlaud, A. and Colasse, B. (2011), Reponse aux commentaires sur "Normalisation comptable internationale : le retour du politique ?", Comptabilité-contrôle-audit, vol. 17, no. 3, pp. 115119, DOI 10.3917/cca.173.0115.

8. Burlaud, A. and Niculescu, M. (2016), Un drept contabil care face appel la raționamentul profesional: 0 amenințare sau o oportunitate pentru profesia contabilă? Audit Financiar, vol. 14, nr. 144, pp. 1267-1276, DOI 10.20869/auditf/2016/144/1325.

9. Burlaud, A. (2017), La transparence peut-elle devenir un principe comptable ? Actuel Expertscomptables, Editions Législatives, 13 juin.

10. Burlaud, A., Poitrinal, F.D. and Salustro, E. (1998), Comptabilité et droit comptable - L'intelligence des comptes et leur cadre legal, Gualino.

11. Capron, M. (1993), La comptabilité en perspective, La Découverte, $128 \mathrm{p}$.

12. Causse, G. (2009), Développement et comptabilité, Encyclopédie de comptabilité, contrôle de gestion et audit, (coord. Colasse, B.), Economica, p. 689703.

2 See also Burlaud and Colasse (2010b,c) 
13. Causse, G., Gouadain, D. and Mifetou, R. (2011), Le SYSCOHADA à l'heure des interrogations, Comptabilité, contrôle et société, Foucher, pp. 129144.

14. Causse, G. and Ebondo Wa Mandzila, E. (2015), Les normes comptables dans les pays de I'UEMOA : apport ou frein au développement ?, in Dynamique normative - Arbitrer et négocier la place de la norme dans l'organisation, coord. Cappelletti et al., Éditions EMS, pp. 39-49.

15. CNUCED (2009), Manuel de statistiques, p. 9.

16. Colasse, B. (2008), La comptabilité comme instrument de modélisation, in Le management Fondements et renouvellements, Schmidt (coord.) Éditions des sciences humaines, pp. 185-193.

17. Degos, J.-G. (1998), Histoire de la comptabilité, PUF, Que sais-je?

18. Disle, C., Perier, S., Bertrand, F., GonthierBesacier, N. and Protin, P. (2016), Business Model et normalisation comptable : quelle intégration du modèle économique pour les IFRS ?, Comptabilité, contrôle, audit, vol. 22, issue 1, pp. 85-119, DOI 10.3917/cca.221.0085.

19. Fourastié, J. (1976), La comptabilité, Collection Que sais-je ? PUF, 128 p.

20. Garnier, P. (1947), La comptabilité, algčbre du droit et méthode d'observation des sciences économiques, Dunod.

21. Haas, J. (2014), Derrière le désordre normatif mondial, l'ignorance du droit, in Normalisation comptable - Actualités et enjeux, L'Académie des sciences techniques comptables financières, $\mathrm{pp}$. 20-22.

22. Haas, J. (2011a), Discours prononcé le 6 avril 2011 à la réunion de l'Association française des trésoriers d'entreprise (AFTE), intitulé « Le merveilleux projet de création d'une norme comptable mondiale unique».

23. Haas, J. (2011b), Entretien publié dans les Petites Affiches $n^{\circ} 44$, du 3 mars 2011, p. 5, intitulé «ll faut trouver un juste équilibre entre normes locales et normes internationales $»$.

24. IASB (2010), The Conceptual Framework for Financial Reporting, available online at http://www.ifrs.org//FRSs/Pages/IAS.aspx, accessed October 2012.

25. Kott, S. (2014), Le concept de système juridicocomptable à l'épreuve de la normalisation internationale, in Normalisation comptable Actualités et enjeux, L'Académie des sciences techniques comptables financières, p. 39-46.

26. Marx, K.H. (1868), Le capital. Livre II, tome 2, Collection La Pléiade, Gallimard, 2112 p.

27. Muller, Y. (2014), L'évolution des relations de la comptabilité à l'économie et au droit, in Normalisation comptable - Actualités et enjeux, L'Académie des sciences techniques comptables financières, pp. 34-38.

28. Nobes, C. (2011), International Variations in IFRS Adoption and Practice, ACCA, Research Report 124, $44 \mathrm{p}$.

29. Plihon, D. (coord.) (2013), Oral d'économie, Foucher.

30. Raybaub-Turrillo, B. and Teller, R. (2009), Droit et Comptabilité, Encyclopedie de comptabilite, controle de gestion et audit (coord. Colasse, B.), pp. 705-717.

31. Rossignol, J-L. (1999), Comptabilité et fiscalité : chronique d'une relation « impérieuse ", Comptabilité, contrôle, audit, vol. 5, no. 2, pp. 5-24, DOI 10.3917/cca.052.0005.

32. Wikipedia (2017), Investissement direct a l'étranger. 